\title{
EFFECT OF GLUTATHIONE ON THE FREEZABILITY AND IN VITRO FERTILIZING
} POTENTIALS OF BOVINE SPERMATOZOA

\author{
M.R. BADR; MARY G. ABD EL-MALAK and T.A. GHATTAS \\ Artificial Insemination and Embryo Transfer Department, Animal Reproduction Research Institute, Al Haram (P.O.B. \\ 12556), Giza, Egypt. e-mail: magdybadr69@yahoo.com
}

\section{ABSTRACT}

Received at: $20 / 6 / 2012$

Accepted: 13/8/2012
Cryopreservation induces sub lethal damage to the spermatozoa, thereby reduce their fertile life. In the present study, effect of glutathione on bovine semen freezability and in vitro fertilizing potentials were evaluated. Semen was cryopreserved in tris-based extender supplemented with different concentrations of reduced glutathione $(0,0.5,1,2,3$ and $5 \mathrm{mM})$. Semen post-thawing motility, viability and acrosomal integrity, DNA damage, enzymes leakage, total antioxidant capacity (TAC), lipid peroxidation and in vitro fertilizing potentials were assessed. Current results indicated that addition of $2 \mathrm{mM}$ glutathione to semen extender significantly $(\mathrm{P}<0.05)$ improved post-thawing motility, viability and acrosomal integrity $(66.25 \pm 5.54 \%, 169.38 \pm 18.59$ and $12.75 \pm 3.45 \%$, respectively) compared with control $(45.00 \pm 2.89 \%, 95.00 \pm 8.90$ and $23.75 \pm 3.45$ $\%$, respectively). Likewise, at this concentration sperm DNA damage, tail length and tail moment of the cryopreserved semen significantly $(\mathrm{P}<0.05)$ reduced $(1.54 \pm 0.38 \%, 1.58 \pm 0.19 \mu \mathrm{m}$ and $2.95 \pm 1.01$, respectively) compared with control $(6.07 \pm 1.61 \%, 6.12 \pm 1.16 \mu \mathrm{m}$ and $34.61 \pm 6.32$, respectively). Moreover, $2 \mathrm{mM}$ glutathione significantly $(\mathrm{P}<0.05)$ increased TAC $(0.50 \pm 0.07 \mathrm{m \mu} / \mathrm{ml})$ and decreased lipid peroxidation of the cryopreserved spermatozoa $(9.68 \pm 2.72$ $\mathrm{nmol} / \mathrm{ml})$ with respect to the control $(0.19 \pm 0.01 \mathrm{m \mu} / \mathrm{ml}$, and $24.82 \pm 4.90$ $\mathrm{nmol} / \mathrm{ml}$, respectively). Additionally, $2 \mathrm{mM}$ glutathione significantly $(\mathrm{P}<0.05)$ improved in vitro fertilization rate, cleavage rate and development to morula and blastocyst stages $(56.78 \pm 12.85,50.18 \pm 6.88,24.68 \pm 5.75$ and $17.66 \pm 3.19 \%$, respectively) compared with the control $(28.10 \pm 2.21,27.01 \pm 4.15,8.80 \pm 10.4$ and $3.90 \pm 2.31 \%$, respectively). It was concluded that the addition of $2 \mathrm{mM}$ glutathione to the freezing extender improved freezability and enhanced in vitro fertilizing potentials of bovine spermatozoa through protection of DNA from deterioration and reduction of oxidative stress.

Key words: Glutathione, cryopreservation, bovine semen, DNA integrity, antioxidant activity.

\section{INTRODUCTION}

Artificial insemination has been widely performed, especially in dairy cows, but the pregnancy is still dependent on the success of semen preservation technology. Freezing of the spermatozoa accelerates the reactive oxygen species (ROS) production. Excessive generation of ROS causes oxidative damage to the spermatozoa affecting their structure and function (Baily et al., 2000; Bilodeau et al., 2001 and Gadea et al., 2004). Despite the fact that the high content of polyunsaturated fatty acids in sperm plasma membrane is required to maintain unique functions at the cellular level, it makes the sperm highly susceptible to the oxidative stress, mainly because of higher lipid peroxidation levels (Maxwell and Watson 1996 and Kankofer et al., 2005). Lipid peroxydation in the plasma membranes are the key mechanism of ROS that causes damage and infertility of sperm cells (Sikka 1996). However, addition of antioxidants in the extender has been reported to improve the quality of preserved mammalian semen (Bilodeau et al., 2001).

Glutathione is a tripeptide, sulfhydril (-SH) antioxidant ( $\gamma$-Glu-Cys-Gly) naturally occurring in semen and providing intracellular defense to the sperm against the oxidative stress caused by an overproduction of ROS during the freezing and thawing process (Gadea et al., 2007). Moreover, semen cryopreservation causes a significant reduction in the glutathione content of the boar (Gadea et al., 2004) and bull semen (Bilodeau et al., 2000). Glutathione addition to the semen extender is expected to reduce or prevent the presence of free radicals that potentially damage the plasma membrane and consequently enhance the fertilizing potentials of the cryopreserved spermatozoa. Therefore, the present study was conducted to determine the effect of various concentrations of the reduced glutathione in semen 
extender on bovine semen freezability and in vitro fertilizing potentials.

\section{MATERIALS and METHODS}

\section{Semen collection and processing:}

Semen samples were collected from six fertile bulls. Only semen samples of at least $70 \%$ initial motility and $800.00 \times 10^{6}$ sperm cells $/ \mathrm{ml}$ were used. After collection, semen samples were pooled, split into 6 portions and diluted at $30{ }^{\circ} \mathrm{C}$ with Tris-based extender (7\% glycerol and 20\% egg yolk), supplemented with different concentrations of glutathione $(0,0.5,1,2,3$ and $5 \mathrm{mM} \%)$. the extended semen was cooled to $5{ }^{\circ} \mathrm{C}$ throughout 60 minute in a cold cabinet. The cooled semen was loaded into $0.25 \mathrm{ml}$ French straws (IMV, L'Aigle, France), then lowered into liquid nitrogen vapor inside foam box for 15 minutes. The straws were then immersed into liquid nitrogen and stored until analysis. Frozen semen samples were thawed in a water bath at $37{ }^{\circ} \mathrm{C}$ for 30 second. Post-thawing sperm motility, viability and acrosomal integrity were assessed according to Mohammed et al. (1998).

\section{Assessment of sperm DNA integrity:}

The DNA integrity and the incidence of DNA strand breaks or fragmentation was detected using alkaline comet assay according to Boe-Hansen (2005). Briefly, The DNA status of individual cells was determined by the neutral single cell gel electrophoresis (comet) assay. For this assay, frozen-thawed spermatozoa were diluted in phosphate buffer saline (PPS), embedded in agarose, followed by cell lysis, DNA decondensation, electrophoresis and DNA staining with $50 \mu \mathrm{l}$ of $20 \mu \mathrm{g} / \mathrm{ml}$ ethidium bromide (Sigma). The cells were then visualized by fluorescent microscopy. Intact nuclei in the comet assay appeared to have compact and brightly fluorescent heads; in contrast, strand breaks in damaged cells allow DNA migration during electrophoresis, and a tail of DNA could be seen behind the head, giving the appearance of a comet (Hughes et al., 1996). After subjecting spermatozoa to the comet assay, sperm nuclei were analyzed by computer soft ware program.

\section{Biochemical analysis:}

Aspartate-aminotransferase (AST), alanineaminotransferase (ALT) and alkaline phosphatase (ALP) enzymes leakage during cryopreservation was assessed according to Tietz (1976) to evaluate the membrane stabilizing effect of glutathione. Additionally, total antioxidant activity and membrane lipid peroxidation, was estimated by the end point generation of malondialdehyde (MDA) determined by the thiobarbituric acid (TBA) test, of the cryopreserved spermatozoa were measured as described by Cortossa et al. (2004).

\section{Evaluation of in vitro fertilizing potential of the treated semen:}

The fertilizing potentials of the semen were assessed using in vitro fertilization technology, as demonstrated by Totey et al. (1992). Three straws from each treatment were thawed in a water bath at $37^{\circ} \mathrm{C}$ for $30 \mathrm{sec}$. The most motile spermatozoa were separated by swim up technique in the fertilization medium, modified Tyrode's Albumin-LactatePyruvate (TALP) containing $6 \mathrm{mg} / \mathrm{ml}$ bovine serum albumin (BSA), for 1 hour as recorded by Parrish et al. (1988). The uppermost layer of the medium containing the most spermatozoa was collected and washed twice by centrifugation at $2000 \mathrm{rpm}$ for 10 minutes. The sperm pellet was resuspended in the fertilization TALP medium containing $10 \mu \mathrm{g} / \mathrm{ml}$ heparin. After appropriate dilution, $2 \mu$ of sperm suspension was added to the fertilization drops, containing the in vitro matured oocytes, at a final concentration $2 \times 10^{6}$ sperm cell $/ \mathrm{ml}$. Gametes were co-incubated in the fertilization drops under sterile mineral oil for 18 hour at $39^{\circ} \mathrm{C}$ in an atmosphere of $5 \% \quad \mathrm{CO}_{2}$ in air with maximum humidity. The inseminated oocytes were freed from extra cumulus cells and attached spermatozoa by gentle pipetting and then cultured in TCM-199 medium for seven days in the same previous conditions. The proportional of cleaved oocytes was recorded 48 hour after insemination and those developed to the morula and blastocyst stages were recorded at 5-7 day postinsemination.

\section{Statistical analysis:}

All data were analyzed by using Costat Computer Program (1986) Cottort Software, and were compared by the least significant difference least (LSD) at $1 \%$ and $5 \%$ levels of probability. The results were expressed as means \pm S.E.M.

\section{RESULT}

The results presented in table 1 revealed that, addition of reduced glutathione to the freezing extender improved the freezability of bull spermatozoa compared with the control semen, in a dose-dependent trend. Addition of $2 \mathrm{mM}$ glutathione to semen extender, appeared to be the best concentration that increased $(\mathrm{P}<0.05)$ significantly the post-thawing sperm motility, viability index and maintained acrosomal integrity $(66.25 \pm 5.54 \%, 169.38 \pm 18.59$ and $12.75 \pm 3.45 \%$, respectively) compared with the control semen $(45.00 \pm 2.89 \%, 95.00 \pm 8.90$ and $23.75 \pm 3.45 \%$, respectively). 
Table 1: Effect of different reduced glutathione concentrations on bovine spermatozoa freezability.

\begin{tabular}{lcccc}
\hline Treatment & $\begin{array}{c}\text { Diluted semen } \\
\text { motility (\%) }\end{array}$ & $\begin{array}{c}\text { Post-thawing } \\
\text { motility }(\%)\end{array}$ & Viability index & $\begin{array}{c}\text { Acrosomal integrity } \\
(\%)\end{array}$ \\
\hline Control & $80.00 \pm 2.04^{\mathrm{a}}$ & $45.00 \pm 2.89^{\mathrm{b}}$ & $95.00 \pm 8.90^{\mathrm{b}}$ & $23.75 \pm 3.45^{\mathrm{a}}$ \\
\hline $0.5 \mathrm{mM}$ glutathione & $82.50 \pm 1.44^{\mathrm{a}}$ & $55.00 \pm 2.04^{\mathrm{ab}}$ & $131.18 \pm 6.95^{\mathrm{a} b}$ & $16.50 \pm 2.60^{\mathrm{ab}}$ \\
\hline $1 \mathrm{mM}$ glutathione & $80.00 \pm 2.06^{\mathrm{a}}$ & $53.75 \pm 3.75^{\mathrm{ab}}$ & $133.13 \pm 20.95^{\mathrm{ab}}$ & $16.00 \pm 3.34^{\mathrm{ab}}$ \\
\hline $2 \mathrm{mM}$ glutathione & $83.75 \pm 1.25^{\mathrm{a}}$ & $66.25 \pm 5.54^{\mathrm{a}}$ & $169.38 \pm 18.59^{\mathrm{a}}$ & $12.75 \pm 3.45^{\mathrm{b}}$ \\
\hline $3 \mathrm{mM}$ glutathione & $81.25 \pm 2.39^{\mathrm{a}}$ & $56.25 \pm 5.15^{\mathrm{ab}}$ & $136.88 \pm 16.10^{\mathrm{b}}$ & $15.00 \pm 3.16^{\mathrm{ab}}$ \\
\hline $5 \mathrm{mM}$ glutathione & $78.75 \pm 2.39^{\mathrm{a}}$ & $47.50 \pm 10.50^{\mathrm{b}}$ & $90.00 \pm 17.99^{\mathrm{b}}$ & $24.50 \pm 3.75^{\mathrm{a}}$ \\
\hline
\end{tabular}

Values with different superscript letters in the same columns are significantly different at least $(\mathrm{P}<0.05)$.

Data regarding the effect of glutathione addition to the freezing extender on the total antioxidant capacity (TAC) and lipid peroxidation of the cryopreserved semen are presented in table 2 . In vitro provision of semen extender with $2 \mathrm{mM}$ glutathione significantly $(\mathrm{P}<0.05)$ increased the total antioxidant capacity and diminished lipid peroxidation of the frozen-thawed semen $(0.50 \pm 0.07 \mathrm{m \mu} / \mathrm{ml}$ and $9.68 \pm 2.72 \mathrm{nmol} / \mathrm{ml}$, respectively) compared with the control extender $(0.19 \pm 0.01 \mathrm{m \mu} / \mathrm{ml}$, and $24.82 \pm 4.90 \mathrm{nmol} / \mathrm{ml}$, respectively). Moreover, data presented in table 2 clarified that, addition of $2 \mathrm{mM}$ glutathione to the semen extender maintained sperm cell membrane integrity and this appeared through reduction of AST, ALT and ALP enzymes leakage $(55.75 \pm 1.75,19.50 \pm 2.48$, $20.87 \pm 3.49 \mathrm{U} / \mathrm{L}$, respectively) compared with the control extender $(100.25 \pm 7.73,26.5 \pm 2.10$ and $26.40 \pm 2.89$ $\mathrm{U} / \mathrm{L}$, respectively).

Table 2: Effect of different reduced glutathione concentrations on biochemical activity of bovine spermatozoa.

\begin{tabular}{|c|c|c|c|c|c|}
\hline Treatment & $\begin{array}{l}\text { AST } \\
(\mathrm{U} / \mathrm{L})\end{array}$ & $\begin{array}{l}\text { ALT } \\
(\mathrm{U} / \mathrm{L})\end{array}$ & $\begin{array}{l}\text { ALP } \\
(\mathrm{U} / \mathrm{L})\end{array}$ & $\begin{array}{c}\text { TAC } \\
(\mathrm{m} \mu / \mathrm{ml})\end{array}$ & $\begin{array}{l}\text { Malondialdyhide } \\
(\mathrm{nmol} / \mathrm{ml})\end{array}$ \\
\hline Control & $100.25 \pm 7.73^{\mathrm{a}}$ & $26.5 \pm 2.10^{\mathrm{a}}$ & $26.40 \pm 2.89^{\mathrm{a}}$ & $0.19 \pm 0.01^{\mathrm{b}}$ & $24.82 \pm 4.90^{\mathrm{a}}$ \\
\hline $0.5 \mathrm{mM}$ glutathione & $93.75 \pm 4.15^{\mathrm{a}}$ & $21.50 \pm 1.34^{\mathrm{ab}}$ & $20.38 \pm 2.74^{b}$ & $0.36 \pm 0.05^{\mathrm{a}}$ & $17.35 \pm 0.94^{\mathrm{ab}}$ \\
\hline $1 \mathrm{mM}$ glutathione & $82.25 \pm 9.29^{\mathrm{ab}}$ & $21.25 \pm 3.73^{\mathrm{ab}}$ & $23.15 \pm 1.10^{\mathrm{ab}}$ & $0.38 \pm 0.05^{\mathrm{a}}$ & $15.39 \pm 2.52^{\mathrm{ab}}$ \\
\hline $2 \mathrm{mM}$ glutathione & $55.75 \pm 1.75^{\mathrm{c}}$ & $19.50 \pm 2.48^{\mathrm{b}}$ & $20.87 \pm 3.49^{\mathrm{ab}}$ & $0.50 \pm 0.07^{\mathrm{a}}$ & $9.68 \pm 2.72^{b}$ \\
\hline $3 \mathrm{mM}$ glutathione & $65.00 \pm 8.92^{b c}$ & $17.25 \pm 1.75^{\mathrm{b}}$ & $16.13 \pm 1.65^{\mathrm{b}}$ & $0.36 \pm 0.06^{\mathrm{a}}$ & $16.67 \pm 4.65^{\mathrm{ab}}$ \\
\hline $5 \mathrm{mM}$ glutathione & $98.75 \pm 7.18^{\mathrm{a}}$ & $23.00 \pm 2.12^{\mathrm{ab}}$ & $21.88 \pm 4.17^{\mathrm{ab}}$ & $0.18 \pm 0.04^{b}$ & $20.75 \pm 2.92^{\mathrm{a}}$ \\
\hline
\end{tabular}

Values with different superscript letters in the same columns are significantly different at least $(\mathrm{P}<0.05)$.

$\mathrm{TAC}=$ Total antioxidant capacity $\mathrm{AST}=$ Aspartate-aminotransferase ALT: Alanine-aminotransferase ALP: Alkaline phosphatase.

With respect to the effect of glutathione addition to the freezing extender on the DNA integrity of the frozen-thawed bovine spermatozoa are demonstrated in table 3 and fig (1). The present data indicated that, in vitro provision of semen extender with $2 \mathrm{mM}$ glutathione significantly $(\mathrm{P}<0.05)$ decreased the DNA fragmentation, tail length and tail moment of the frozen-thawed semen $(1.54 \pm 0.38 \%, 1.58 \pm 0.19 \mu \mathrm{m}$ and $2.95 \pm 1.01$, respectively) as compared with the control extender $(6.07 \pm 1.61 \%, 6.12 \pm 1.16 \mu \mathrm{m}$ and $34.61 \pm 6.32$, respectively). 


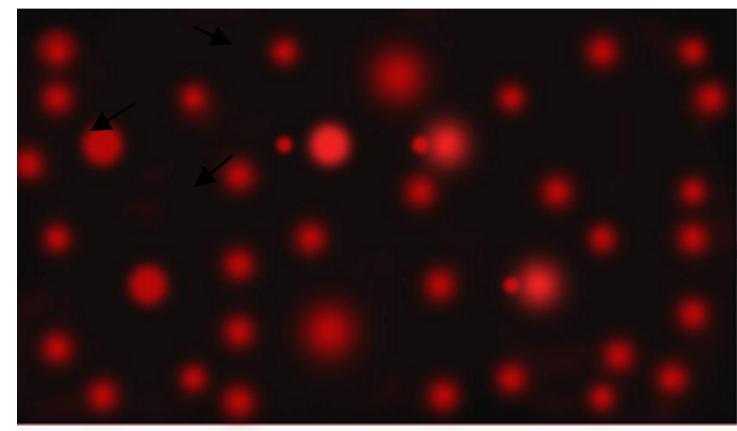

a

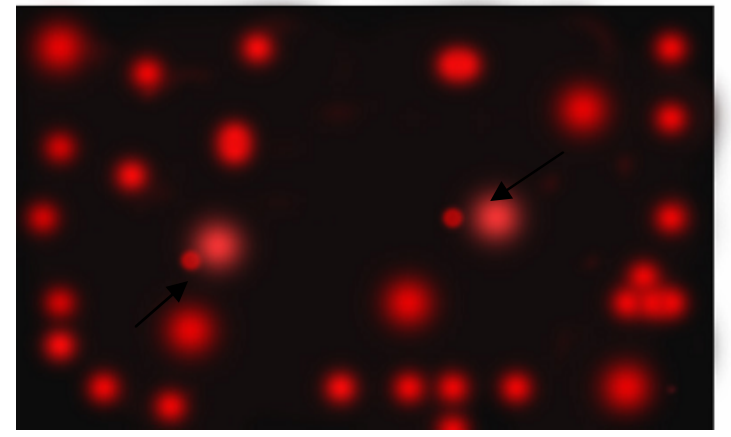

b

Fig. 1 (a-: The single cell gel electrophoresis (comet) assay showed reduction in the DNA fragmentation as represented by a limited amount of DNA present in the comet tail bovine spermatozoa cryopreserved in tris$2 \mathrm{mM}$ glutathione.- (b). The single cell gel electrophoresis (comet) assay showed increased in the DNA fragmentation of the bovine spermatozoa cryopreserved in control extender.

Table 3: Effect of different glutathione concentrations on DNA integrity of bovine spermatozoa.

\begin{tabular}{lccc}
\hline Treatment & DNA integrity $(\%)$ & Tail length $(\mu \mathrm{m})$ & Tail moment \\
\hline Control & $6.07 \pm 1.61^{\mathrm{a}}$ & $6.12 \pm 1.16^{\mathrm{a}}$ & $34.61 \pm 6.32^{\mathrm{a}}$ \\
\hline $0.5 \mathrm{mM}$ glutathione & $3.26 \pm 0.91^{\mathrm{ab}}$ & $2.46 \pm 0.91^{\mathrm{b}}$ & $7.96 \pm 2.09^{\mathrm{b}}$ \\
\hline $1 \mathrm{mM}$ glutathione & $2.44 \pm 0.31^{\mathrm{b}}$ & $2.00 \pm 0.53^{\mathrm{b}}$ & $4.72 \pm 1.14^{\mathrm{b}}$ \\
\hline $2 \mathrm{mM}$ glutathione & $1.54 \pm 0.38^{\mathrm{b}}$ & $1.58 \pm 0.19^{\mathrm{b}}$ & $2.95 \pm 1.01^{\mathrm{b}}$ \\
\hline $3 \mathrm{mM}$ glutathione & $2.67 \pm 0.57^{\mathrm{b}}$ & $2.12 \pm 0.62^{\mathrm{b}}$ & $3.87 \pm 1.03^{\mathrm{b}}$ \\
\hline $5 \mathrm{mM}$ glutathione & $5.91 \pm 1.27^{\mathrm{a}}$ & $5.32 \pm 0.90^{\mathrm{a}}$ & $30.07 \pm 4.88^{\mathrm{a}}$ \\
\hline
\end{tabular}

Values with different superscript letters in the same columns are significantly different at least $(\mathrm{P}<0.05)$.

Data concerning the effect of replenishing of semen extender with glutathione on the in vitro fertilizing potentials and embryo development are presented in tables 4 and 5 . The current results revealed that, addition of $2 \mathrm{mM}$ glutathione to the freezing extender had a positive effect $(\mathrm{P}<0.05)$ on the in vitro fertilization and embryo developmental rates compared with the control semen. When $2 \mathrm{mM}$ glutathione was added to the freezing extender, a higher proportion of in vitro fertilized oocytes, cleavage rate, morula and blastocyst development $(56.78 \pm 12.85,50.18 \pm 6.88,24.68 \pm 5.75$ and $17.66 \pm 3.19 \%$, respectively) compared with the control $(28.10 \pm 2.21$, $27.01 \pm 4.15,8.80 \pm 10.4$ and $3.90 \pm 2.31 \%$, respectively).

Table 4: Effect of different glutathione concentrations on the in vitro fertilizing potentials of bovine spermatozoa.

\begin{tabular}{lccccc}
\hline Treatment & $\begin{array}{c}\text { No. of } \\
\text { oocytes }\end{array}$ & $\begin{array}{c}\text { No. of } \\
\text { Penetrated } \\
\text { oocytes }\end{array}$ & $\begin{array}{c}\text { Penetration rate } \\
(\%)\end{array}$ & $\begin{array}{c}\text { No. of } \\
\text { fertilized } \\
\text { oocytes }\end{array}$ & $\begin{array}{c}\text { Fertilization rate } \\
(\%)\end{array}$ \\
\hline Control & 83 & 48 & $57.75 \pm 14.43^{\mathrm{a}}$ & 24 & $28.10 \pm 2.21^{\mathrm{b}}$ \\
\hline $0.5 \mathrm{mM}$ glutathione & 68 & 43 & $59.20 \pm 9.16^{\mathrm{a}}$ & 27 & $43.73 \pm 7.62^{\mathrm{ab}}$ \\
\hline $1 \mathrm{mM}$ glutathione & 61 & 37 & $60.10 \pm 5.30^{\mathrm{a}}$ & 25 & $39.58 \pm 9.91^{\mathrm{ab}}$ \\
\hline $2 \mathrm{mM}$ glutathione & 87 & 60 & $67.67 \pm 7.32^{\mathrm{a}}$ & 51 & $56.78 \pm 12.85^{\mathrm{a}}$ \\
\hline $3 \mathrm{mM}$ glutathione & 69 & 41 & $56.81 \pm 9.06^{\mathrm{a}}$ & 29 & $40.35 \pm 9.66^{\mathrm{ab}}$ \\
\hline $5 \mathrm{mM}$ glutathione & 61 & 42 & $68.81 \pm 7.34^{\mathrm{a}}$ & 17 & $27.86 \pm 1.49^{\mathrm{b}}$ \\
\hline
\end{tabular}

Values with different superscript letters in the same columns are significantly different at least $(\mathrm{P}<0.05)$. 
$\underline{\text { Assiut Vet. Med. J. Vol. } 58 \text { No } 134 \text { July } 2012}$

Table 5: Effect of different glutathione concentrations on in vitro bovine embryo development.

\begin{tabular}{|c|c|c|c|c|}
\hline Treatment & No. of oocytes & $\begin{array}{c}\text { Cleavage rate } \\
\text { No. }(\%)\end{array}$ & $\begin{array}{c}\text { Morula stage } \\
\text { No. }(\%)\end{array}$ & $\begin{array}{c}\text { Blastocyst stage } \\
\text { No. }(\%)\end{array}$ \\
\hline Control & 79 & $21(27.01 \pm 4.15)^{b}$ & $6(8.80 \pm 10.4)^{b}$ & $3(3.90 \pm 2.31)^{b}$ \\
\hline $0.5 \mathrm{mM}$ glutathione & 88 & $34 \quad(38.42 \pm 4.49)^{\mathrm{ab}}$ & $13(14.02 \pm 4.88)^{\mathrm{ab}}$ & $8(8.86 \pm 1.45)^{b}$ \\
\hline $1 \mathrm{mM}$ glutathione & 63 & $27 \quad(42.17 \pm 7.17)^{\mathrm{ab}}$ & $11(17.68 \pm 3.70)^{\mathrm{ab}}$ & $7(11.23 \pm 1.92)^{\mathrm{ab}}$ \\
\hline $2 \mathrm{mM}$ glutathione & 81 & $43(50.18 \pm 6.88)^{\mathrm{a}}$ & $20(24.68 \pm 5.75)^{\mathrm{a}}$ & $14(17.66 \pm 3.19)^{\mathrm{a}}$ \\
\hline $3 \mathrm{mM}$ glutathione & 78 & $26(32.97 \pm 8.66)^{\mathrm{ab}}$ & $12(12.73 \pm 3.15)^{a b}$ & $6(7.58 \pm 4.07)^{b}$ \\
\hline $5 \mathrm{mM}$ glutathione & 73 & $19(26.57 \pm 5.08)^{\mathrm{b}}$ & $(7.21 \pm 2.72)^{b}$ & $3(4.22 \pm 2.20)^{b}$ \\
\hline
\end{tabular}

Values with different superscript letters in the same columns are significantly different at least $(\mathrm{P}<0.05)$.

\section{DISCUSION}

The current results clarified that, addition of glutathione to the freezing extender prior to cryopreservation improved the freezability and the assisted fertilizing potentials of the frozen-thawed bovine spermatozoa. These results are in agreement with previous studies (Gadea et al., 2005 and Kawakami et al., 2007). This protective effect on sperm function was dose dependent. Addition of 2 $\mathrm{mM}$ glutathione into the semen diluent is sufficiently effective to improve spermatozoal freezability and in vitro fertilizing potentials. These results are in accordance with the previous results that revealed that the beneficial effect of glutathione is dose dependant, in goat (Sinha et al., 1996), cow (Foote et al., 2002) and buffalo (Badr et al., 2009).

It is well known that cryopreservation induces the formation of ROS which is detrimental to the sperm function (Watson, 2000). ROS generation during sperm cryopreservation, accompanied by low scavenging and antioxidant levels in spermprocessing extender will induce a state of oxidative stress (Hellstrom et al., 1994). The authors further added that, high levels of ROS endanger sperm motility, viability, and function by interacting with membrane lipids, proteins and mitochondrial DNA. These observations may explain the results of the current study that emphasized that; cryopreservation of bovine spermatozoa is associated with damage of sperm function affecting the processes required for the successful fertilization. Moreover, the link between ROS and reduced motility may be due to a cascade of events that result in a decrease in axonemal protein phosphorylation and sperm immobilization, both of which are associated with a reduction in membrane fluidity (de Lamirande and Gagnon, 1995).

Moreover, it is well established that sperm cells are susceptible to lipid peroxidation during cryopreservation; that damages the sperm cell structure and eventually lowered metabolism and motility of the cells (Chatterjee and Gagnon, 2001). Lipid peroxides, derived from peroxidation of polyunsaturated fatty acids, are unstable and decompose to form a complex series of compounds. These include reactive carbonyl compounds, of which the most abundant is MDA (Mennella and Jones, 1980). Therefore, measurement of MDA is widely used as an indicator of lipid peroxidation in a variety of cell types, including spermatozoa (Sikka, 1996). The current results demonstrated that the presence of glutathione in the freezing extender reduced MDA production in frozen-thawed spermatozoa. These results corroborate the hypothesis that one of the most beneficial effects of glutathione during the cryopreservation is reduction of the membrane lipid peroxidation, throughout reduction of lipid peroxidation.

Besides membrane damage and impairment of motility, lipid peroxidation can damage the DNA in the sperm nucleus, either through oxidation of DNA bases or through covalent binding to MDA, resulting in strand breaks and cross linking (Sikka, 1996). Recently, it was proposed that lipid peroxyl radicals induce DNA damage and an apoptotic signaling cascade in endothelial cells (Kotamraju et al., 2001). Moreover, it is claimed that DNA deterioration and apoptosis occurs as a result of cryodamage in mammalian cells (Slowińska et al., 2008 and Badr et al., 2010). This damage may be attributed to the oxidative stress, which is detrimental to sperm DNA integrity (Fraser and Strzeźek, 2005). These studies may explain the current results that showed, cryopreservation in the glutathione-free extender, are associated with increased DNA deterioration. However, glutathione could be an important regulator of the scavenging system and one of the most important antioxidants in sperm cells (Griveau and Le Lannou, 1997 and Gadea et al., 2005). Therefore, the positive effect of GSH on the sperm freezability and fertilizing potentials observed in the current study may be attributed to its ability to protect sperm against oxidative damage and reduction of oxidative stress-induced DNA oxidation and DNA fragmentation (Agarwal and Said, 2003 and Funahashi and Sano, 2005). Moreover, sperm DNA integrity is important for the fertilization success and normal embryonic development, spermatozoa with incomplete chromatin condensation fertilize a very low percentage of ova in vitro or fail to fertilize, even 
after direct injection of spermatozoa into the ovum (Lopes et al., 1998 and Ahmadi and Ng, 1999). Sperm DNA damage will be associated with collateral peroxidative damage to the sperm plasma membrane, consequently the plasma membrane loses the fluidity and integrity that is necessary for spermoocyte fusion and can therefore compromise the fertilizing potentials of the sperm or resulting in a low rate of embryonic development (Sakkas et al., 2002). This hypothesis is indicated in the present study where the lowest MDA levels and DNA deterioration were measured when a glutathione concentration of $2 \mathrm{mM}$ was used, which was the concentration that achieved the highest rate of embryo development in vitro.

However, the results of the present study confirmed that, inclusion of increasing levels of glutathione in the semen extender induced a drastic effect on sperm function. These results are in accordance with Aitken et al. (1998) who indicated that, high levels of antioxidants are associated with impaired sperm function and this may be due to the spermatozoa become more susceptible to the cytotoxic effect of $\mathrm{H}_{2} \mathrm{O}_{2}$ or the removal of the $\mathrm{O}_{2}$ which is an important mediator of normal sperm function. Therefore, it is important to select the appropriate antioxidant concentrations to maintain the natural balance that exists between ROS generation and scavenging activities (Bamba and Cran 1992 and Badr et al., 2009). It seems, therefore, that the addition of glutathione to semen extenders has beneficial or detrimental effects on post-thaw sperm survival depending on the concentration used, with the maximum concentration required for effectiveness being $2 \mathrm{mM}$.

In conclusion, the data presented in this study demonstrated that the presence of glutathione in the freezing extender at concentrations of $2 \mathrm{mM}$ improved the freezability and in vitro fertilizing potentials of bovine spermatozoa. The current results also suggest that the protective effect of glutathione on cryopreserved spermatozoa is directly related to a reduction in lipid peroxidation and protection of sperm DNA from deterioration.

Acknowledgments: We wish to thank Dr H.M. Hassen (ARRI) for the helpful effort in the Comet assay and critical reading of the comet results.

\section{REFERENCES}

Agarwal, A. and Said, T.M. (2003): Role of sperm chromatin abnormalities and DNA damage in male infertility. Hum. Reprod. Update, 9: $331-345$.

Ahmadi, A. and Ng, S.C. (1999): Fertilizing ability of DNA-damaged spermatozoa. J. Exp. Zool., 284: 696-704.

Aitken, R.J.; Gordon, E.; Harkiss, D.; Twigg, J.P.; Milne, P.; Jennings, Z. and Irvine, D.S. (1998): Relative impact of oxidative stress on the functional competence and genomic integrity of human spermatozoa. Biol. Reprod., 59: 1037-1046.

Badr, M.R.; Abd el Hafez, S.M. and Eman, M. Abd el Fatah (2009): Influence of antioxidants on DNA integrity, mitochondrial function and fertilizing potentials of cryopreserved buffalo spermatozoa. Assiut Vet. Med. J., 55 (120): 296-317.

Badr, M.R.; Mary G. Abd El- Malak and Hassan, H.M. (2010): Effect of trehalose on cryopreservation, oxidative stress and DNA integrity of buffalo spermatozoa. J. Reproduction and infertility, 1 (2): 50-57.

Bailey, J.L.; Bilodeau, J.F. and Cormier, N. (2000): Semen cryopreservation in domestic animals: A damaging and capacitating phenomena. J. Andrology, 22: 508-515.

Bamba, K. and Cran, D.G. (1992): Effect of treatment with butylated hydroxytoluene on the susceptibility of boar spermatozoa to cold stress and dilution. J. Reprod. Fertil., 95: 69-77.

Bilodeau, J.F.; Chatterjee, S.; Sirard, M.A. and Gagnon, C. (2000): Levels of antioxidant defenses are decreased in bovine spermatozoa after a cycle of freezing and thawing. Mol. Reprod. Dev., 55: 282 -288.

Bilodeau, J.F.; Blanchette, S.; Gagnon, C. and Sirard, M.A. (2001): Thiols prevent $\mathrm{H} 2 \mathrm{O} 2$ mediated loss of sperm motility in cryopreserved bull semen. Theriogenology, 56: 275-286.

Boe-Hansen, G.B. (2005): Hydrogen peroxide alters the physical state and function of the plasma membrane of pulmonary artery endothelial cells. J. Cellular Physiology, 20: 362-374.

Chatterjee, S. and Gagnon, C. (2001): Production of reactive oxygen species by spermatozoa undergoing cooling, freezing and thawing. Mol. Reprod. Dev.; 59: 451-458.

Cortossa, S.; Aon, M.A.; Waston, R.L. and O'Rourke, B. (2004): A mitochondrial oscillator dependent on reactive oxygen species. Biopysic. J, 87: 2060-2073.

Costat Computer Program (1986): Version 3.03 copyright Cottort Software.

De Lamirande, E. and Gagnon, C. (1995): Impact of reactive oxygen species on spermatozoa: a balancing act between beneficial and detrimental effects. Hum. Reprod., 10 (suppl 1): 15-21.

Foote, P.A.; Brocket, C.C. and Caproth, M.T. (2002): Motility and fertility of bull in whole milk extender containing antioxidant. Anim. Reprod. Sci. 71: 13-23.

Fraser, L. and Strzeźek, J. (2005): Effects of freezing-thawing on DNA integrity of boar spermatozoa assessed by the neutral comet assay. Reprod. Domest. Anim., 40: 530-536.

Funahashi, H. and Sano, T. (2005): Select antioxidants improve the function of extended boar semen stored at $10{ }^{\circ} \mathrm{C}$. Theriogenology; 63: $1605-1616$. 
Gadea, J.; Selles, E.; Marco, M.A.; Coy, P.; Matas, C.; Romar, R. and Ruiz, S. (2004): Decrease in glutathione content in boar sperm after cryopreservation; Effect of the addition of reduced glutathione to the freezing and thawing extenders. Theriogenology, 62: 690701.

Gadea, J.; García-Vazquez, F.A.; Matás, C.; Gardón, J.C.; Cánovas, S. and Gumbao, D. (2005): Cooling and freezing of boar spermatozoa: Supplementation of the freezing media with reduced glutathione preserves sperm function. J. Androl., 26: 396-404.

Gadea, J.; Gumbao, D.; Novas s, C.; Zquez, F.A.Z.; Grullo, L.A. and Gardo, G.C. (2007): Supplementation of the dilution medium after thawing with reduced glutathione improves function and the in vitro fertilizing ability of frozen-thawed bull spermatozoa. Andrology, 7: 1-10.

Griveau, J.F. and Le Lannou, D. (1997): Reactive oxygen species and human spermatozoa: physiology and pathology. Int. J. Androl., 20: $61-69$.

Hellstrom, W.J.G.; Bell, M.; Wang, R. and Sikka, S.C. (1994): Effect of sodium nitroprusside on sperm motility, viability and lipid peroxidation. Fertil. Steril., 61: 1117-1122.

Hughes, C.M.; Lewis, S.E.; McKelvey-Martin, V.J. and Thompson, W. (1996): A comparison of baseline and induced DNA damage in human spermatozoa from fertile and infertile men, using a modified comet assay. Mol. Hum. Reprod., 2: 613- 619.

Kankofer, M.; Kolm, G. and Aurich, J. (2005): Activity of glutathione peroxidase, superoxide dismutase and catalase and lipid peroxidation intensity in stallion semen during storage at 5 oC. Theriogenology, 63: 1354-1365.

Kawakami, E.; Takemura, A.; Sakuma, M.; Takano, M.; Hirano, T. and Tsutsui, T. (2007): Superoxide dismutase and catalase activites in the seminal plasma of normozoospermic and asthenozoospermic beagles. J. Vet. Med. Sci., 69(2): 133-136.

Kotamraju, S.; Hogg, N.; Joseph, J. and Keefer, L.K. (2001): Inhibition of oxidized lowdensity lipoprotein-induced apoptosis in endothelial cells by nitric oxide.J. Biol. Chem., 276: 17316-17323.

Lopes, S.; Sun, J.G.; Jurisicova, A.; Meriano, J. and Casper, R.F. (1998): Sperm deoxyribonucleic acid fragmentation is increased in poor-quality semen samples and correlates with failed fertilization in intracytoplasmic sperm injection. Fertil. Steril., 69(3): 528-532.

Maxwell, W.M.C. and Watson, P.F. (1996): Recent progress in the preservation of ram semen. Anim. Reprod. Sci. 42: 55-65.

Mennella, M.R.F. and Jones, R. (1980): Properties of spermatozoal superoxide dismutase and lack of involvement of superoxides in metal-ioncatalyzed lipid peroxidation reactions in semen. J. Biochem., 191: 289-297.

Mohammed, K.M.; Ziada, M.S. and Darwish, G.M. (1998): Practical trials for freezing semen of buffalo and Friesian bulls: Effect of various regimens of freezing, different milk extenders and types of straws packages on post-thawing semen characters. Assiut Vet. Med. J, 39 (77): 70-93.

Parrish, J.J.; Susko-Parrish, J.; Winer, M.A. and First, N.L. (1988): Capacitation of bovine sperm by heparin. Biol. Reprod., 38: 11711180.

Sakkas, D.; Moffatt, O.; Manicardi, G.; Mariethoz, E.; Tarozzi, N. and Bizzaro, D. (2002): Nature of DNA damage in ejaculated human spermatozoa and possible involvement of apoptosis. Biol. Reprod., 66: 1061-1067.

Sikka, S.C. (1996): Oxidative stress and role of antioxidant in normal and abnormal sperm function. Frontier Biosci., 1: 78-86.

Sinha, M.P.; Sinha, A.K.; Singh, B.K. and Prasad, P.L. (1996): The effect of glutathione on the motility, enzyme leakage and fertility of frozen goat semen. Theriogenology, 41: 237243.

Slowińska, M.; Karal, H. and Ciereszko, A. (2008): Comet assay of fresh and cryopreserved bull spermatozoa. Cryobiology, 56: 100-102.

Tietz, N.W. (1976): Fundamentals of clinical chemistry. W.B. Saunders Company, Philadelphia.

Totey, S.M.; Singh, G.P.; Taneja, M.; Pawshe, C.H. and Talwar, G.P. (1992): In vitro maturation, fertilization and development of follicular oocytes from buffalo (Bubalus bubalis). J. Reprod. Fertil., 95: 597-607.

Watson, P.F. (2000): The cause of reduced fertility with cryopreserved semen. Anim. Reprod. Sci., 60-61: 481-492. 


\section{دراسة تأثير الجلوتاثيون علي قابليه حيامن الأبقار للتجميد وكفاءتها الإخصابية معمليا}

مجبي رمضان بلر ، ماري جاد عبل الملاك ، طة عبل القادر غطاس

أجري هذا البحث لدراسة تأثير اضافة الجلوتاثيون الي ممدد السائل المنوى علي قابلية حيامن الأبقار للتجميد وكذا قدرتها الاخصابية معمليا. تم

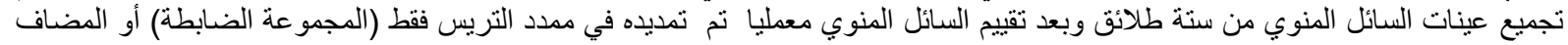

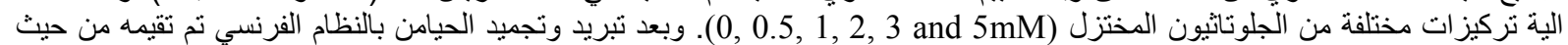

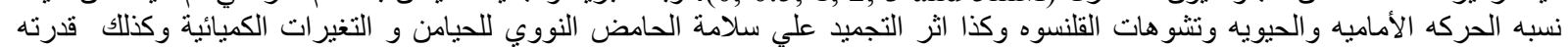

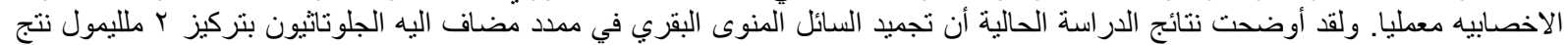

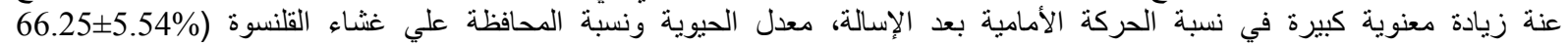

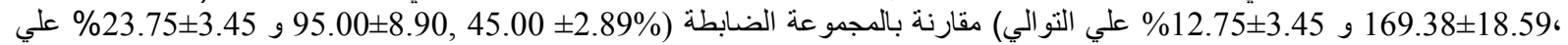

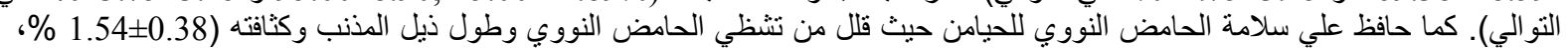

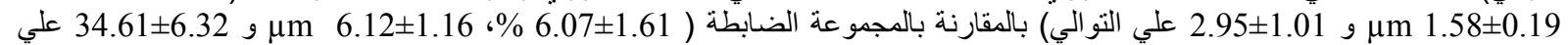

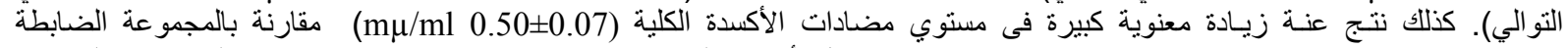

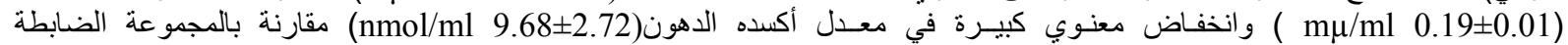

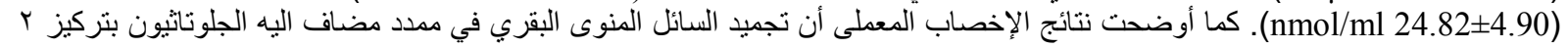

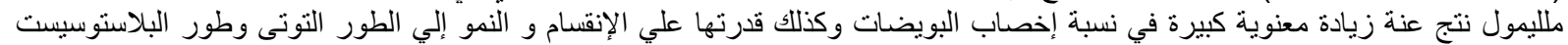

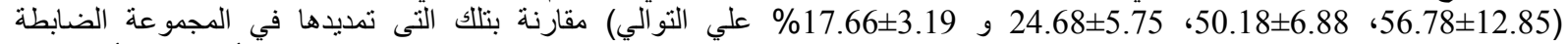

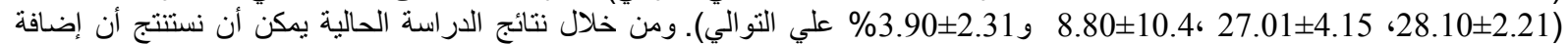

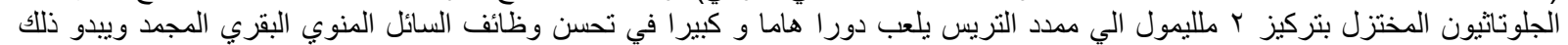

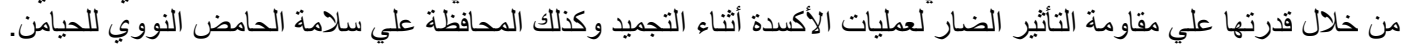

